\title{
Seismic Hazard Assessment at the Fallon, Nevada, Frontier Observatory for Research in Gbothermal Energy Site
}

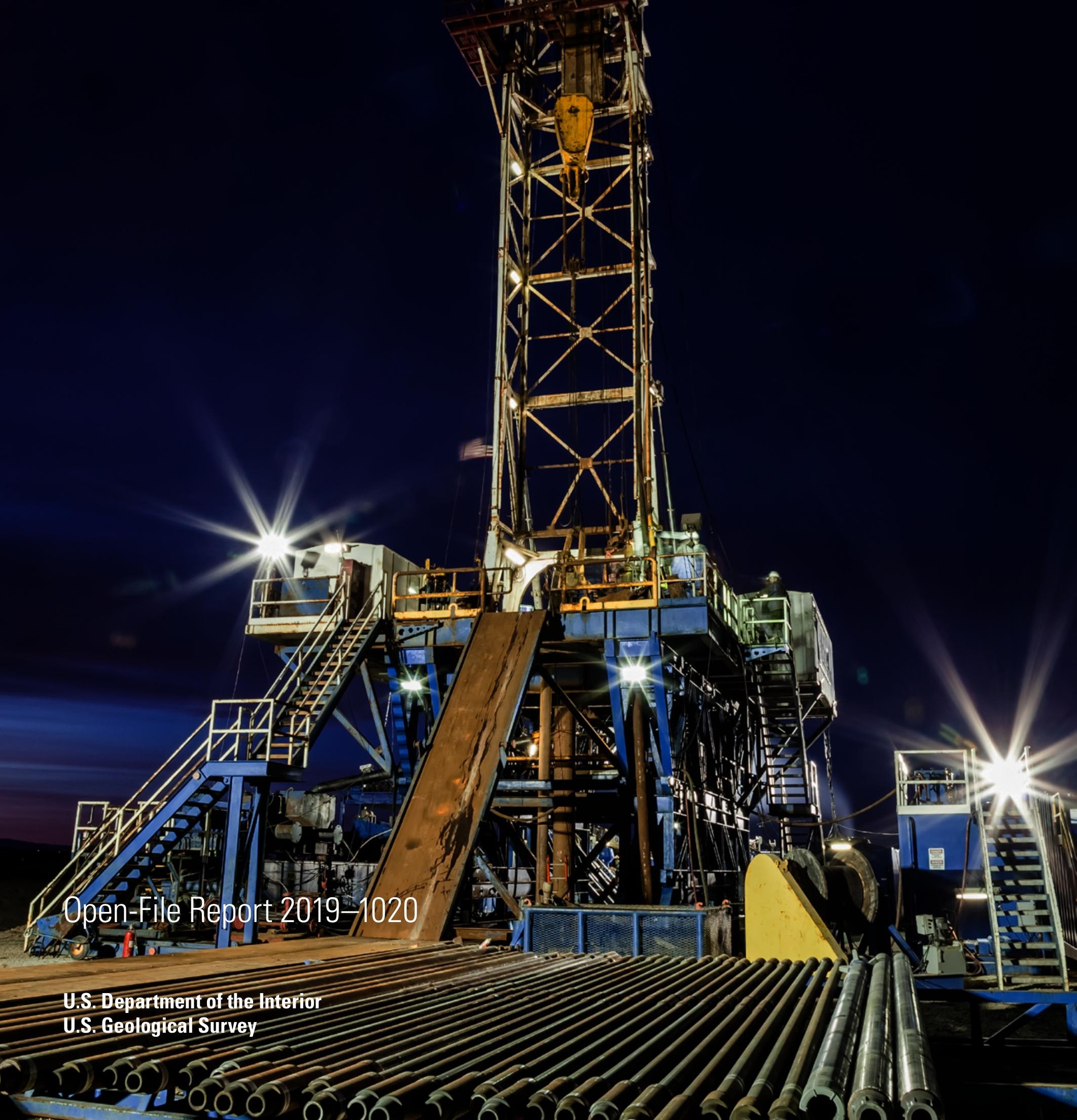


Cover Image. Drill rig at the Fallon Frontier Observatory for Research in Geothermal Energy (FORGE) site during exploration well drilling. Image courtesy of Bridget Ayling. 


\section{Seismic Hazard Assessment at the Fallon, Nevada, Frontier Observatory for Research in Geothermal Energy Site}

By J. Ole Kaven, Ernest L. Majer, William Foxall, Eric L. Sonnenthal, and

William Pettitt

Open-File Report 2019-1020 


\title{
U.S. Department of the Interior \\ DAVID BERNHARDT, Acting Secretary
}

\author{
U.S. Geological Survey \\ James F. Reilly II, Director
}

U.S. Geological Survey, Reston, Virginia: 2019

For more information on the USGS - the Federal source for science about the Earth, its natural and living resources, natural hazards, and the environment-visit https://www.usgs.gov or call 1-888-ASK-USGS.

For an overview of USGS information products, including maps, imagery, and publications,

visit https://store.usgs.gov.

Any use of trade, firm, or product names is for descriptive purposes only and does not imply endorsement by the U.S. Government.

Although this information product, for the most part, is in the public domain, it also may contain copyrighted materials as noted in the text. Permission to reproduce copyrighted items must be secured from the copyright owner.

Suggested citation:

Kaven, J.O., Majer, E.L., Foxall, W., Sonnenthal, E.L., Pettitt, W., 2019, Seismic hazard assessment at the Fallon, Nevada, Frontier Observatory for Research in Geothermal Energy site: U.S. Geological Survey Open-File Report 2019-1020, 16 p., https://doi.org/10.3133/ofr20191020.

ISSN 2331-1258 (online) 


\section{Contents}

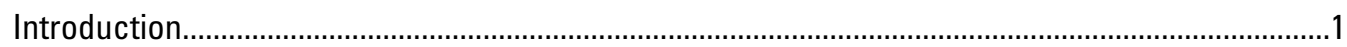

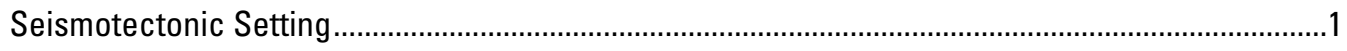

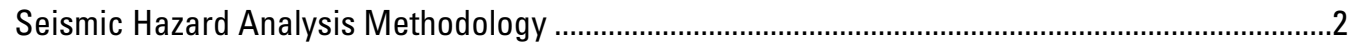

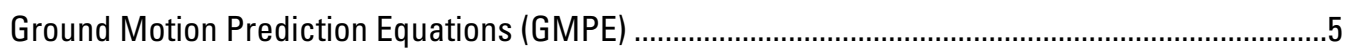

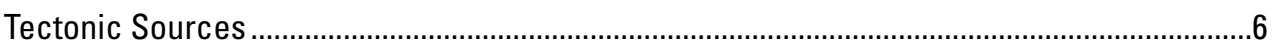

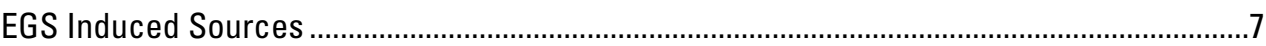

Deterministic Sources: Geomechanical Model-3DEC ...........................................................

Deterministic Sources: Geomechanical Model-TReactMech ...............................................10

Deterministic Sources: Injection and Rigidity Model ............................................................10

Deterministic Sources: Analog sites .................................................................................... 10

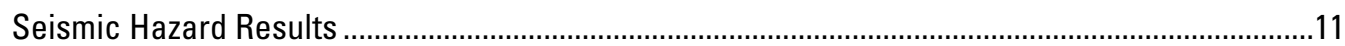

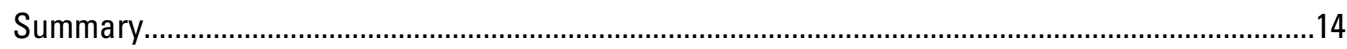

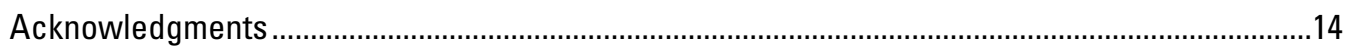

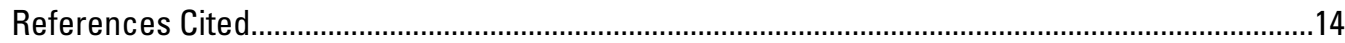

\section{Figures}

1. Historic seismicity and seismic hazard in the vicinity of the proposed Fallon, Nevada, Frontier Observatory for Research in Geothermal Energy site .................................................... 2

2. 3D geologic model of the region around the Fallon Frontier Observatory for Research in Geothermal Energy site............................................................................................................... 3

3. Logic tree of enhanced geothermal systems (EGS) induced and natural tectonic probabilistic seismic hazard assessment (PSHA) analyses.

4. Regional peak ground acceleration data in $\mathrm{m} / \mathrm{s}^{2}$ versus moment magnitude for various distances plotted with three ground motion prediction equations ..........................................5

5. Regional Vs30 map used for site response at each of the significant sites considered specifically in this analysis.

6. Probability of exceedance of ground motion versus peak ground acceleration (PGA) in $g$ at the Fallon Naval Air Station for three probability density functions (PDF) of rupture distances $\left(\mathrm{R}_{\text {rup }}\right)$ compared to the annual tectonic seismic hazard ................................................ 8

7. Spatial distribution of the simulated microseismic cloud for the two conceptual treatment designs .....

8. Cumulative seismic moment as a function of total injected volume at various injection sites

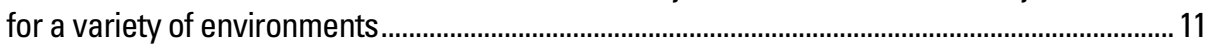

9. Probability of exceedance of peak ground acceleration (PGA) at the Naval Air Station in Fallon, Nevada.

10. Probability of exceedance of peak ground acceleration (PGA) at the Banner Churchill community hospital.

11. Probability of exceedance of peak ground acceleration (PGA) in downtown Fallon, Nevada

12. Probability of exceedance of ground motion (PGA) at Rattlesnake Hill. 


\section{Tables}

1. Vs30 at the significant sites used in the probabilistic seismic hazard analysis (PSHA) ..6

2. Major faults and source characteristics used in the USGS National Seismic Hazard Map for natural seismic hazard assessment................................................................ 


\title{
Seismic Hazard Assessment at the Fallon, Nevada, Frontier Observatory for Research in Geothermal Energy Site
}

\author{
By J. Ole Kaven ${ }^{1}$, Ernest L. Majer ${ }^{2}$, William Foxall ${ }^{2}$, Eric L. Sonnenthal ${ }^{2}$, and William Pettitt ${ }^{3}$
}

\section{Introduction}

Enhanced geothermal systems (EGS) technology aims to engineer a productive geothermal reservoir in regions of hot, but low permeability, rocks. This technology has been explored for some time (Dash and others, 1981; Kraft and Deichmann, 2014), but many questions remain to be solved before EGS can become a viable, widespread addition to the energy production portfolio. In any EGS operation, the rock mass requires stimulation by high pressure injection of fluids, which has the potential to induce seismicity. EGS projects have experienced induced seismicity large enough to cause damage, for example, Basel, Switzerland 2006 (Kraft and Deichmann, 2014) and Pohang, South Korea 2017 (Kim and others. 2018), ultimately ending some projects. One potential EGS site is the Fallon, Nevada, Frontier Observatory for Research in Geothermal Energy (FORGE), a Department of Energy (DOE) funded research initiative aimed to answer and test many questions related to EGS.

Given the potential for inducing seismicity and the associated shaking hazard, stimulation scenarios require careful consideration including site characterization and assessment throughout various stages of a project to minimize the seismic hazard of such stimulation. To address the seismic hazard specifically, a probabilistic seismic hazard assessment (PSHA) is often required and is generally part of an induced seismicity mitigation plan (ISMP). The purpose of a PSHA is to estimate the ground shaking hazard at locations in the vicinity of a proposed EGS site due to natural (tectonic) and induced seismicity. This is a critical step toward assessing the probability of exceeding the criteria specified as part of an ISMP (Majer and others, 2012). Seismic hazard refers to ground motions produced by earthquakes and a seismic hazard analysis addresses the probabilities of such ground motions over a specified interval of time. While an earthquake can present several types of hazards, we are primarily concerned with ground shaking due to induced seismic events.

\footnotetext{
${ }^{1}$ U.S. Geological Survey.

${ }^{2}$ Lawrence Berkeley National Laboratory, California.

${ }^{3}$ Itasca now at Geothermal Resources Council.
}

A specific PSHA for the proposed Fallon, Nev., FORGE site is outlined below that relies solely on hypothetical stimulation scenarios and analog sites to assess the hazard of induced seismicity in the absence of local microseismicity. We begin by reviewing the tectonic setting and natural seismicity in the region and then expand on the methods used in probabilistic seismic hazard analyses. This is followed by a discussion of the results and evaluation of ground shaking at significant sites in the vicinity of the Fallon FORGE site.

\section{Seismotectonic Setting}

The tectonic setting near the Fallon FORGE site controls in large part the seismic activity that is experienced naturally and the seismicity that may be induced by injection activities. The Fallon FORGE site is located in the western part of the Great Basin, a broad part of the Basin and Range Province, that undergoes significant extensional deformation due to the relative motion between the Pacific and North American tectonic plates to the west (fig. 1). A broad zone of shearing across Western North America from the San Andreas Fault to the Basin and Range Province accommodates the inter-plate deformation. At the western edge of the Great Basin the Walker Lane, a zone of strike-slip and normal faults, accommodates a large part of this inter-plate deformation (Stewart, 1988). Geodetic data indicate that up to 25 percent of the relative displacement between the plates occurs in the Western Great Basin (for example Thatcher and others, 1999). To the east, the Walker Lane deformation pattern transitions to the Basin and Range Province, which exhibits pervasive normal faulting. This faulting creates the characteristic topography that indicates a largely extensional stress regime from which the region derived its name. Extensional deformation in the Basin and Range Province is thought to originate from back arc spreading (Parsons, 1995).

The two major recent tectonic processes contributing to the development of possibly seismogenic faults in the area began with regional east-west extension from early Miocene time to present followed by dextral shear from the late Miocene to present associated with Pacific-North American Plate motion, northwestward propagation of the Walker Lane into the region, and concomitant retreat of the ancestral Cascade arc to the northwest (Siler and others, 2018). The northern Walker Lane 

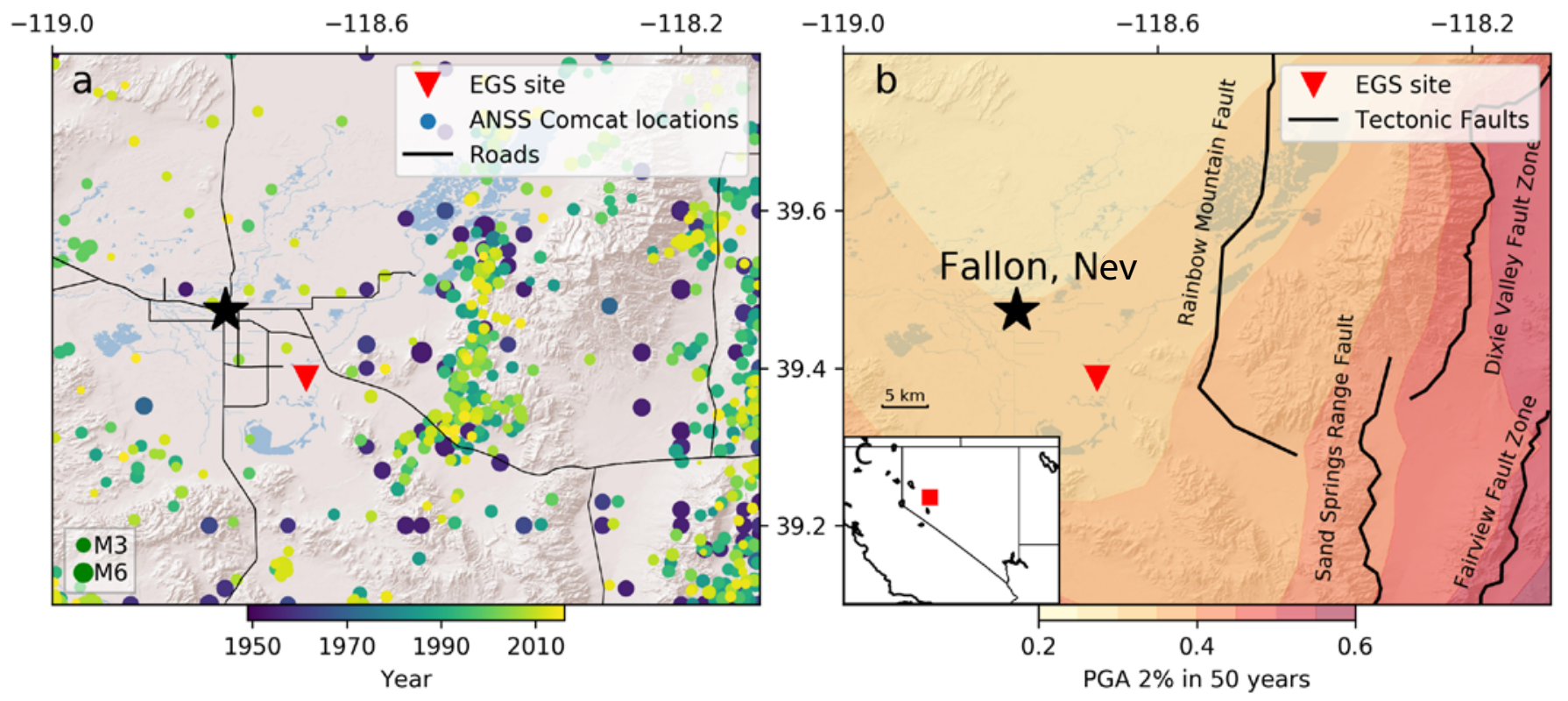

Figure 1. (A) Historic seismicity in the vicinity of the proposed Fallon, Nevada, Frontier Observatory for Research in Geothermal Energy (FORGE) site, marker sizes scale with magnitude and color indicates year of event. ( $B$ ) Tectonic seismic hazard in the vicinity of the proposed EGS site. Red triangle indicates location of EGS site. (C) (Inset) Location map of the detailed maps shown in $A$ and $B$. Geographic extents in $A$ and $B$ are identical.

directly to the west and to the northwest of Fallon is one of the youngest parts of the Pacific-North American Plate boundary, having developed in the past $\sim 5$ million years (Faulds and Henry, 2008). The southeastern Carson Sink, a basin structure within the Basin and Range Province (Morrison, 1964), has relatively high strain rates, as indicated by GPS geodetic data (Hammond and others, 2014; Kreemer and others, 2012).

High strain rates and rocks that are critically stressed for frictional failure have led to significant seismic activity in the instrumented and historic catalogs.

To the east of the Fallon site is the central Nevada seismic zone, which comprises several faults capable of significant magnitude earthquakes. This zone was the site of the 1954 Rainbow Mountain-Stillwater earthquake sequence that included two $M_{\mathrm{S}} 6$ and the $M_{\mathrm{S}} 7.2$ Fairview Peak earthquakes. Historic seismicity in this region includes the $1915 M_{\mathrm{S}} 7.6$ Pleasant Valley and $1932 M_{\mathrm{S}} 7.2$ Cedar Mountain earthquakes to the north and south, respectively (Caskey and others, 2004). Surface rupture during the 1954 Rainbow Mountain-Stillwater earthquake sequence occurred on the east flank of Rainbow Mountain, roughly $10 \mathrm{~km}$ east of the Fallon site (fig. $1 B$ ). The east-dipping fault experienced normal to oblique slip along the northern segment turning to more strike-slip motion to the south.

Quaternary faults are common in the region but are somewhat scarce in the southeastern Carson Sink. Fault kinematic and well-bore data indicate that a west-northwest-trending extension direction has dominated the Carson Sink region from the late Miocene to present (Blake and Davatzes, 2012; Faulds and others, 2010; Hammond and others, 2014; Hickman and
Davatzes, 2010; Hinz and others, 2014; Jolie and others, 2015; Kreemer and others, 2012). Faults identified from seismicreflection and gravity surveys are generally modestly to steeply dipping normal faults, dipping both to the east and west. These faults extend from roughly $200 \mathrm{~m}$ depth at their highest vertical extent to roughly $4 \mathrm{~km}$ depth (Siler and others, 2016). Faults generally trend north to south and are largely confined to the extent of the geologic model (fig. 2), resulting in fault lengths of up to $10 \mathrm{~km}$. The seismic reflection profiles indicate that slip on these faults occurred as recently as the Pleistocene, but as no surface trace is visible these faults have likely not been active in the last $10 \mathrm{k} . \mathrm{yr}$. and were not deformed during the Rainbow Mountain-Stillwater earthquake sequence.

\section{Seismic Hazard Analysis Methodology}

Given the a-priori, unknown induced seismicity potentially generated by injection operations, coupled with the uncertainties in the ingredients that result in ground shaking, a probabilistic seismic hazard analysis (PSHA) is employed to robustly estimate the seismic hazard for a particular site (for example, McGuire, 2004). A PSHA comprises the following ingredients:

- identification of all earthquake sources (faults in the area of interest),

- a distribution of earthquake magnitudes and a rate of recurrence on those faults (maximum considered magnitude, b-value, slip rate), 
- A distribution of source-to-site distances associated with each likely earthquake (possible sites and magnitudes on faults and their location with respect to the site of interest),

- Ground motion prediction equations (GMPE) that describe the ground-motion intensity (peak ground acceleration, velocity, or acceleration or velocity at given spectral periods), as a function of earthquake magnitude, distance, etc. at each location of interest, and,

- Probabilistic assessment of all ingredients and their associated uncertainties (using the total probability theorem).

The pertinent earthquake sources are all faults in the vicinity of the study area, each described by its dip, depth (or width), and relationships to a specific site at which the seismic hazard is of interest, for example sensitive structures or critical facilities. Given a set of earthquake sources, earthquake magnitudes and rates of recurrence of those specific magnitudes on these sources have to be quantified, either from existing historic rates, analog sites, or modeling studies. Finally, the ground motion intensity for a given location, source, and distance is calculated using a variety of GMPEs suitable for the location and magnitude range. Following the total probability theorem, these components are combined to allow the treatment of all likely earthquake sources, magnitudes, recurrences, and ground motions into a single expression, which allows estimation of the probability that a specific ground motion will be exceeded:

$$
\begin{gathered}
\lambda(I M>x)=\sum_{i=1}^{n_{\text {sources }}} \lambda\left(M_{i}>m_{\min }\right) \sum_{j=1}^{n_{M}} \sum_{k=1}^{n_{R}} P\left(I M>x \mid m_{j}, r_{k}\right) \\
P\left(m_{i}=m_{j}\right) P\left(R_{i}=r_{k}\right)
\end{gathered}
$$

where

$$
\begin{aligned}
& \lambda(I M>x) \text { is the rate of exceeding a ground motion } \\
& \text { intensity }(I M) \text { of size } x \text {, summing over } \\
& \text { all causative magnitudes } M_{i} \text {; at } \\
& \text { distances } R_{i} \text {; } \\
& \lambda\left(M_{i}>m_{\min }\right) \text { is the rate of occurrence of earthquakes } \\
& \text { larger than } m_{\text {min }} \text {; } \\
& P\left(I M>x \mid m_{j}, r_{k}\right) \text { is the probability of exceeding that level } \\
& \text { of ground motion } x \text { given a specific } \\
& \text { magnitude and distance measure; } \\
& P\left(m_{i}=m_{j}\right) \text { is the probability of a certain magnitude, } \\
& \text { and } \\
& P\left(R_{i}=r_{k}\right) \text { is the probability of the site of interest } \\
& \text { being distance } r \text { from the source. }
\end{aligned}
$$

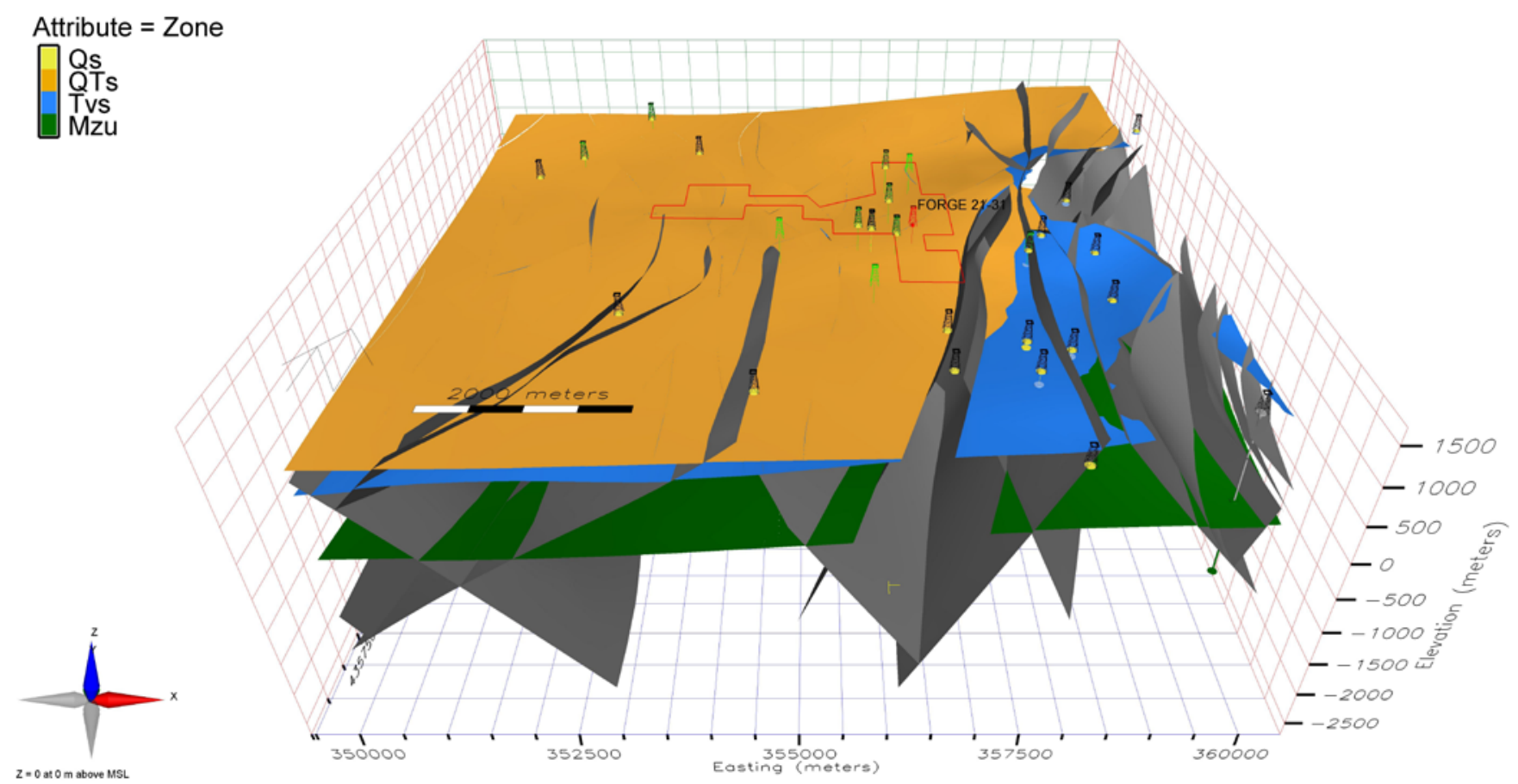

Figure 2. 3D geologic model of the region around the Fallon Frontier Observatory for Research in Geothermal Energy (FORGE) site. Tops of major lithological units are shown in various colors with faults shown in grey and identified from gravity and seismic reflections surveys in black. The lithological units are: Quaternary Soil (Qs), Quaternary Sediments (QTs), Tertiary Volcanics (Tvs), and Mesozoic metasediments and metavolcanics (Mzu). Towers indicate wells and the red outline is the area in which FORGE operations are conducted. Adapted from Siler and others, 2018. 
The area surrounding the Fallon FORGE site is no stranger to significant tectonic seismic activity and, therefore a significant tectonic seismic hazard exists, stemming largely from the Rainbow Mountain-Stillwater and Dixie Valley Faults. These faults are included in the U.S. Geological Survey (USGS) National Seismic Hazard Maps (NSHM), which are based on the same five components outlined above (see also fig. 3).

Any injection or production activity has the potential to activate critically stressed faults in the vicinity of the injection or production site, and therefore the effects of injection on nearby faults are considered in induced EGS scenarios. The induced seismic hazard is often thought of as a modulation of the tectonic seismic hazard. However, we contend that the tectonic seismic hazard and the induced seismic hazard can be treated separately in the present case owing to: (1) the detailed geologic model for the area surrounding the Fallon site, which includes a number of bounding faults; (2) the large distance $(>10 \mathrm{~km})$ from the injection site to the nearest fault included in the NSHM; (3) the small injection volumes in comparison to other sites of fluid injection; and (4) the fact that an analog site with similar injection volumes located at Desert Peak, Nev., produced only low levels of microseismicity (Chabora and others, 2012).

The geologic model encompasses a volume spanning $10 \mathrm{~km}$ by $10 \mathrm{~km}$ by $4 \mathrm{~km}$ and has been extensively studied, in particular for the existence of faults (fig. 2). Localized injection into the model volume would likely affect faults only in the immediate vicinity and even moderate magnitude events on the faults within the model are very unlikely to affect slip on faults more than $10 \mathrm{~km}$ away. The injection volumes, specifically the net injection volumes, are small compared to sites of induced seismicity where more distant faults have been linked to injection activity (for example Goebel and others, 2017). For the aforementioned reasons we treat the induced and natural seismic hazards separately and rely on the USGS National Seismic Hazards Maps for the natural (tectonic) seismic hazard. We list the components for both the induced and natural seismic hazard in the following sections and provide results for both.

\section{Seismic sources GMPEs Source geometry}

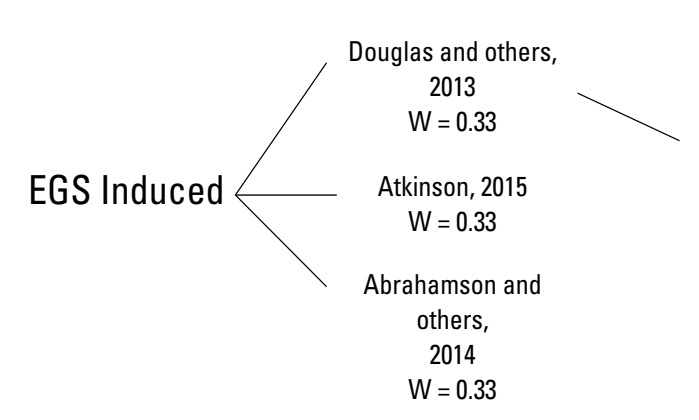

Regional Tectonic

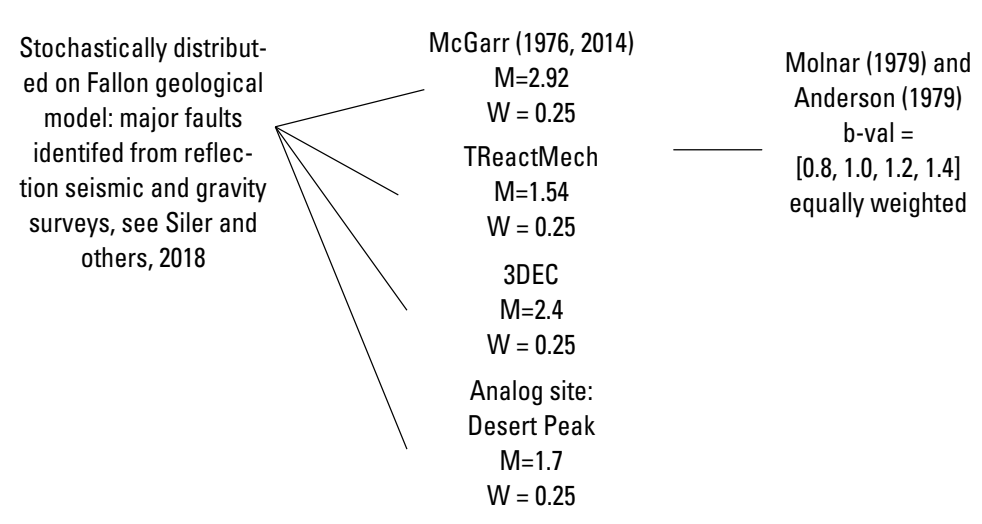

USGS Quarternary
Fault and Fold Database
Mmax

(Max. Considered Magnitude)
Instrumented record \& Wells and Coppersmith (1994) regression relations

Various, for example Caskey and others, 2004 (for Rainbow Mountain Fault)

Figure 3. Logic tree of enhanced geothermal systems (EGS) induced and natural tectonic probabilistic seismic hazard assessment (PSHA) analyses 


\section{Ground Motion Prediction Equations (GMPE)}

We use three separate GMPEs in the analysis of EGSinduced seismic hazard, namely Abrahamson and others (2014), Atkinson (2015), and Douglas and others (2013), to capture the various contributions of the source, path and site effects to predicted ground motion. The GMPE of Abrahamson and others (2014) is included in the EGS-induced seismic hazard analyses as it is also used in the tectonic analyses. We use the other two GMPEs because both are specifically designed for induced, smaller-magnitude seismicity. Figure 4 shows the regional peak ground acceleration (PGA) data (in $\mathrm{m} / \mathrm{s}^{2}$ ) at various distances from the proposed EGS site and superposes the three GMPEs used. No fit of these is performed, but each GMPE captures the general data trends in the plots, whereas Atkinson (2015) appears to capture the decrease in PGA at low magnitudes and close distances better than the other two. However, each GMPE is given equal weight as is often done in PSHA.

For natural, tectonic sources the USGS National Seismic Hazard Map (NSHM) uses a combination of GMPEs that are separately weighted and combined in the logic tree approach of the PSHA (fig. 3). For EGS induced seismicity, we anticipate seismicity less than moment magnitude $\left(M_{\mathrm{w}}\right) 3$; none of the GMPEs used in the USGS-NSHM are developed for $M_{\mathrm{w}}<3$. Hence, for the EGS induced portion of the logic tree, we use a different combination of GMPEs that account for smaller ground motion (Atkinson, 2015; Douglas and others, 2013), and also use Abrahamson and others (2014) as it best models small magnitude ground motions of those used in the USGS-NSHM.

The underlying soil and rock strongly affect the ground motion experienced at any point and are routinely included in the GMPEs. All GMPEs used in this study require that the Vs30 (time-averaged shear-wave velocity down to a depth of $30 \mathrm{~m}$ ) are included to account for local amplification effects in the ground motions (fig. 5). For the GMPEs used in the EGS induced portion of the logic tree, we use the Vs30 values from the USGS Vs30 database (Allen and Wald, 2009) derived from topography only without using local measurements of Vs30. In addition, several GMPEs require a basin term set as the depth to $1 \mathrm{~km} / \mathrm{s}$ shear wave velocity; Boore and others (2014) implicitly uses the median relationship to the Z1.0 depth; Campbell and Bozorgnia (2014) uses the depth to $2.5 \mathrm{~km} / \mathrm{s}$ as the basin predictor term. We use the default values from the USGS-NSHM but set the basin term depth to $500 \mathrm{~m}$ for GMPEs used in the EGS induced portion of
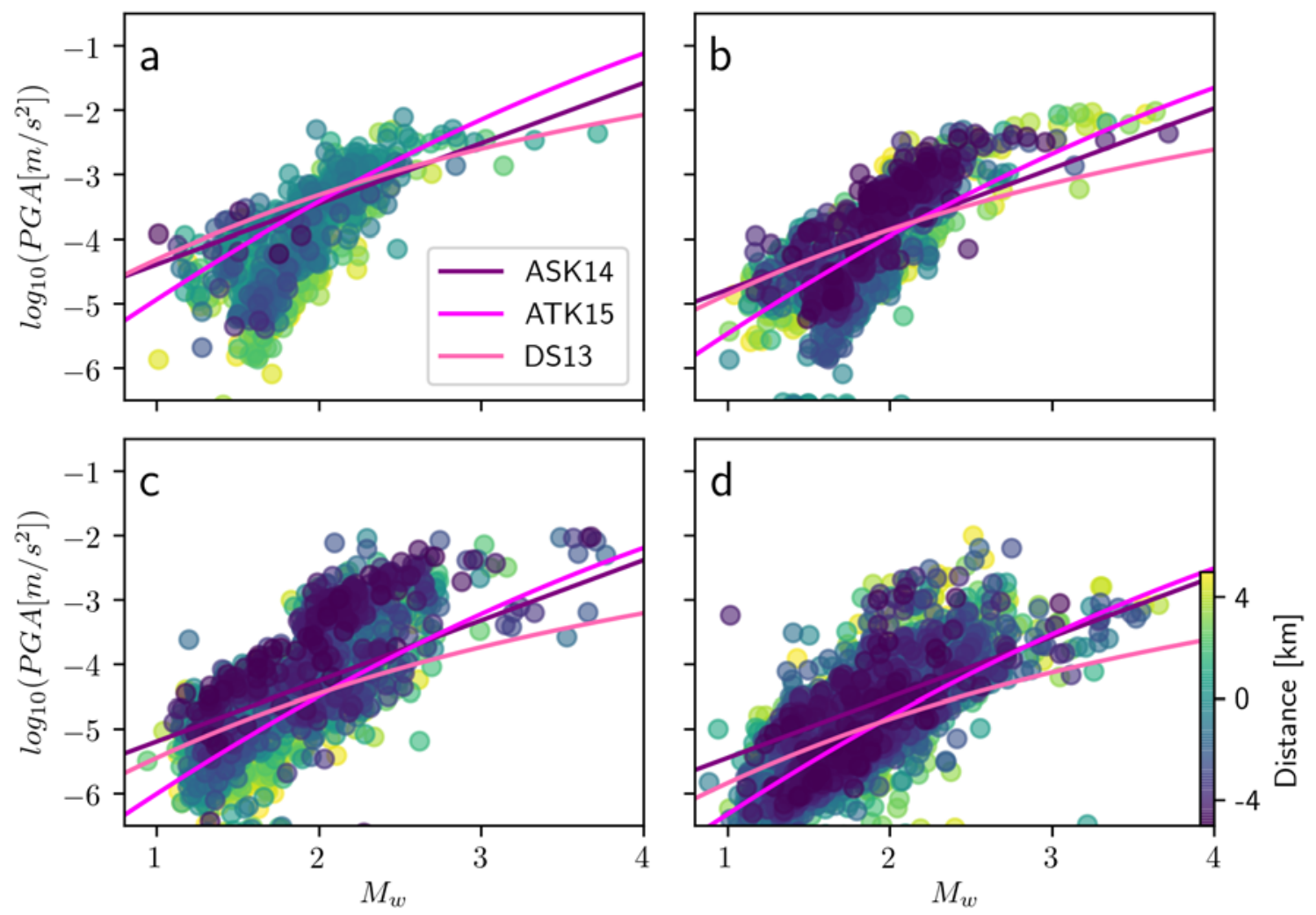

Figure 4. Regional peak ground acceleration data in $\mathrm{m} / \mathrm{s}^{2}$ versus moment magnitude (Mw) for various distances plotted with the three ground motion prediction equations (GMPEs) used in the enhanced geothermal systems (EGS) induced probabilistic seismic hazard analysis (PSHA): ASK14 - Abrahamson and others, 2014, ATK15 - Atkinson, 2015, DS13 - Douglas and others, 2013. ( $A$ ) Data and GMPEs centered around $5 \mathrm{~km} ;(B)$ centered around $10 \mathrm{~km},(C)$ centered around $20 \mathrm{~km},(D)$ centered around $30 \mathrm{~km}$. 
the logic tree. We further set the top of rupture depth to $200 \mathrm{~m}$ in the GMPEs for the EGS induced hazard calculation in accordance with the shallow faults identified in the geologic model. The four significant sites we consider specifically are: Fallon Naval Air Station (NAS) (runway), Banner Churchill Community Hospital, Fallon downtown (Maine St.), and Rattlesnake Hill (fig. 5).

\section{Tectonic Sources}

Tectonic faults in the Fallon region, especially to the east, are plentiful and have been active in recent, instrumented history. The Rainbow Mountain-Stillwater earthquake sequence of 1954 is the most significant and nearest earthquake activity featuring three surface-rupturing earthquakes ranging in magnitude from $M_{\mathrm{S}} 6.3$ to $M_{\mathrm{S}} 7.0$. The sequence occurred on several faults with complicated surface trace patterns and
Table 1. Vs30 at the significant sites used in the probabilistic seismic hazard analysis (PSHA).

[Vs30 is time-averaged shear-wave velocity down to a depth of $30 \mathrm{~m}$ measured in meters per second $(\mathrm{m} / \mathrm{s})]$

\begin{tabular}{ll}
\hline \multicolumn{1}{c}{ Significant site } & Vs30 (m/s) \\
\hline NAS Fallon & 221.5 \\
Banner Churchill Hospital & 222.5 \\
Fallon downtown & 218.5 \\
Rattlesnake Hill & 275.1 \\
\hline
\end{tabular}

varying slip rates. These and additional faults are included in the USGS NSHM and we list the source characteristics of the four nearest faults used in the maps in table 1 .

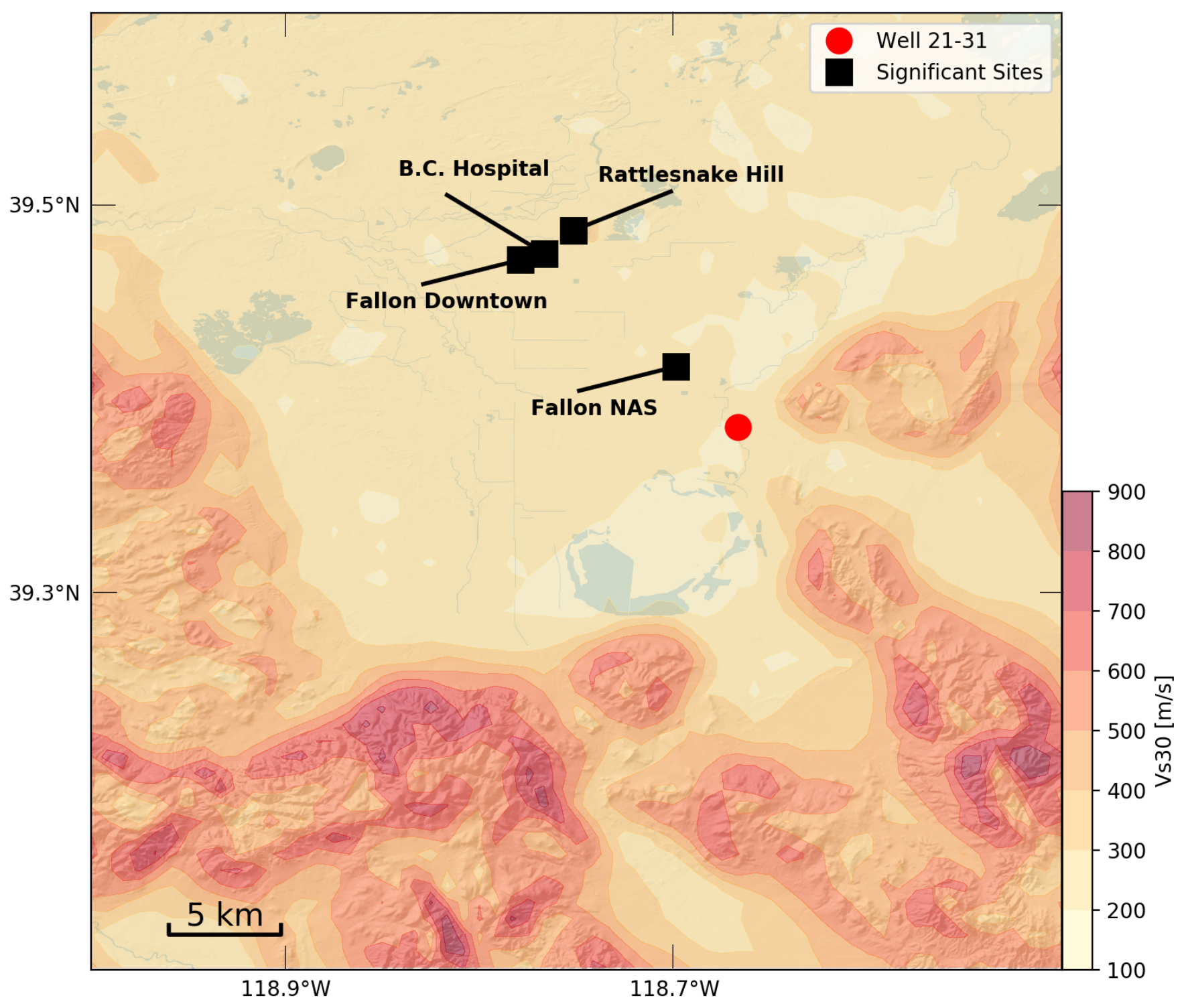

Figure 5. Regional Vs30 map used for site response at each of the significant sites considered specifically in this analysis (Fallon Naval Air Station, Nev., Fallon, Nev. Downtown, Banner Churchill Hospital, and Rattlesnake Hill). Color gradient corresponds to Vs30 in meters per second (m/s). 
Table 2. Major faults and source characteristics used in the U.S. Geological Survey National Seismic Hazard Map for natural seismic hazard assessment.

[Rupture dimensions of faults in kilometers $(\mathrm{km})$ for top, bot. (bottom), and length of displacement; maximum considered moment magnitude (Mmax); and slip rate (w) as measured in millimeters per year (mm/yr). For more details see: https://earthquake.usgs.gov/arcgis/rest/services/haz/hazfaults2014/MapServer]

\begin{tabular}{|c|c|c|c|c|c|c|c|}
\hline Name & Dip $\left(^{\circ}\right)$ & $\begin{array}{c}\text { Rupture } \\
\text { (top/bot./length) } \\
\text { (km) }\end{array}$ & Rake $\left({ }^{\circ}\right)$ & Mmax & b-val & a-val & $\begin{array}{c}\text { Slip Rate (w) } \\
(\mathrm{mm} / \mathrm{yr})\end{array}$ \\
\hline Rainbow Mountain Fault Zone & 90 & $0 / 15 / 72$ & $\begin{array}{c}180 \\
\text { strike slip fault }\end{array}$ & 7.23 & 0.8 & $\begin{array}{l}1.028 \\
1.125 \\
0.957\end{array}$ & $\begin{array}{l}0.2(0.8) \\
0.25(0.1) \\
0.17(0.1)\end{array}$ \\
\hline Sand Springs Range Fault & $50 / 65 / 35$ & $0 / 15 / 42$ & $\begin{array}{c}-90 \\
\text { normal } \\
\text { fault }\end{array}$ & 6.96 & 0.8 & $\begin{array}{l}1.433 \\
1.271\end{array}$ & $\begin{array}{l}0.261(0.8) \\
0.18(0.1)\end{array}$ \\
\hline Dixie Valley Fault Zone & $50 / 65 / 35$ & $0 / 15 / 119$ & -90 & 7.00 & 0.8 & $\begin{array}{l}2.050 \\
2.048 \\
2.190\end{array}$ & $\begin{array}{l}0.392(08) \\
0.39(0.1) \\
0.54(0.1)\end{array}$ \\
\hline Fairview Fault Zone & $50 / 65 / 35$ & $0 / 15 / 34$ & -90 & 7.2 & 0.8 & $\begin{array}{l}0.773 \\
0.888\end{array}$ & $\begin{array}{l}0.131(0.8) \\
0.17(0.1)\end{array}$ \\
\hline
\end{tabular}

\section{EGS Induced Sources}

Faults that are likely to exhibit seismic activity due to the EGS operations are well contained within the geologic model (fig. 2). Because no local seismicity on these faults has been recorded, either by regional seismic networks or by the Navy Geothermal Program Office (GPO) local seismic network, we rely on geomechanical models, an analog site, and simple injection volume and host rock rigidity models to obtain source characteristics necessary for an EGS induced PSHA. These source characteristics are used to distribute possible earthquake sources on the fault model, thereby allowing for more realistically distributed seismicity near the proposed injection site. Several fault characteristics required in the PSHA are common to all faults and are kept constant in this report: rupture depth top $=200 \mathrm{~m}$, rupture depth bottom $4 \mathrm{~km}$, dip $=55$, rake $=-90$ (normal faulting). Additional source characteristics, namely Mmax (maximum considered moment magnitude), Gutenberg-Richter b- and a-value and slip rates are evaluated using geomechanical models, analog site, and injection and rigidity models in the following subsections. All components to the EGS induced PSHA are then included and weighted equally (fig. 3).

The region being considered for EGS stimulation and faults within the geologic model allow for the use of a truncated exponential recurrence relationship (Baker, 2008). The general approach is to relate the earthquake moment of interest, the maximum considered moment, and the b-value to the average return or recurrence period (Molnar, 1979). Given the wide range of possible $b$-values that some models do not constrain (for example injection volume and rigidity) or are limited in their use due to the sparse seismicity recorded (for example. Desert Peak), we elected to test four different $b$-values ranging from 0.8 to 1.4 and add these as individual branches of the logic tree approach (fig. 3). From these b-values, the probability of specific earthquake magnitude frequencies using a bounded Gutenberg-Richter distribution is derived (Baker, 2008).

While comparing various scenarios using synthetic and analog data, possible sites (or rupture distances from sites of significance $\mathrm{R}_{\mathrm{rup}}$ ) are stochastically distributed in the total probability of the exceedance of ground motion calculation. To illustrate the appropriate rupture distance distribution, we test three different cases: (1) a point source at the injection site resulting in one distance from earthquake source to significant site (fig. $6 B$ ); (2) a uniform distribution of rupture distance in the geologic model resulting in equal probability on each fault segment (fig. $6 C$ ) and; (3) normally distributed rupture distances centered on the injection and stimulation wells (fig. $6 D$ ). The last case is the most plausible option where pore pressures and poro-elastic stresses will be highly elevated near the stimulation well and, thus, raise the probability of inducing seismicity near the stimulation the most. This last model is further supported by the results of the geomechanical models that indicate deformation occurs in close proximity to the injection and stimulation well only.

The model with a uniform distribution of rupture distances produced the largest predicted ground motions at low probability of exceedance for the NAS Fallon site (fig 6C). The large predicted ground motions are due to the close proximity of a rupture (near the edge of the geologic model) to the Fallon Naval Air Station (NAS) site. The point source has a significantly decreased PGA compared to the uniformly distributed rupture distances due to the larger separation between the rupture and Fallon NAS site. A normally distributed probability of rupture distances produces the lowest predicted PGA (fig. $6 D$ ). This is due to the probability of being farther from NAS Fallon compared to the point source. Since the final model is the most likely scenario given the localized increase of pore pressures and poro-elastic stresses near the stimulation well and is supported by the results of the geomechanical models, we use the normally distributed rupture distance distribution. 

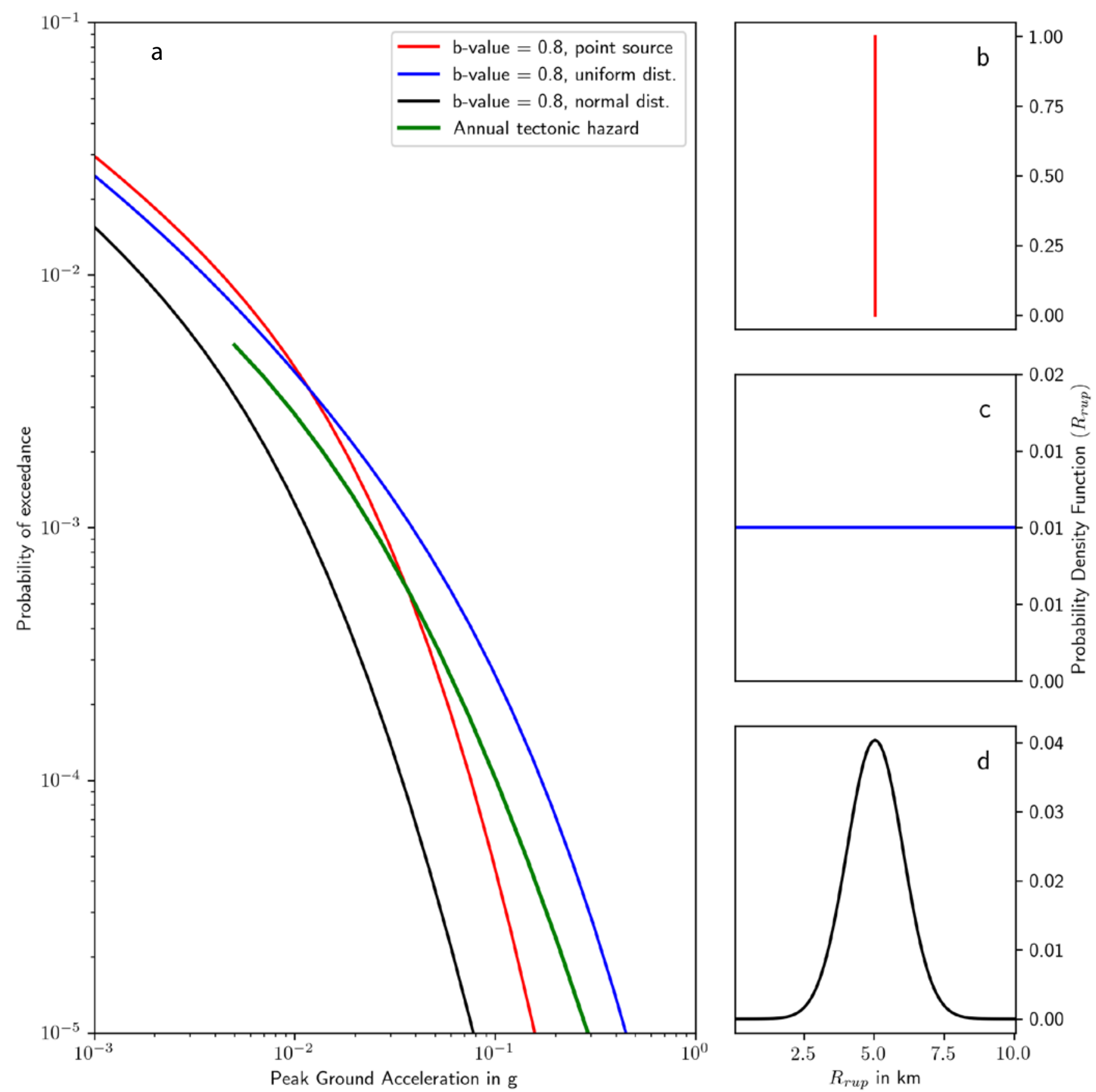

Figure 6. (A) Probability of exceedance of ground motion versus peak ground acceleration (PGA) in $\mathrm{g}$ at the Fallon Naval Air Station for three probability density functions (PDF) of rupture distances $\left(R_{\text {rup }}\right)(B-D)$ compared to the annual tectonic seismic hazard. 
Deterministic Sources: Geomechanical Model 3DEC

Reservoir simulations that include induced and natural fractures inform different initial conceptual designs for well geometries and stimulation strategies for the proposed Fallon FORGE site (Blanksma and others, 2018). The Distinct Element Method (DEM) in the 3DEC software (Itasca Consulting Group) is used to run a suite of coupled three-dimensional thermo-hydromechanical (THM) models that consider the geological site characterization, design concepts, and criteria for the project. It includes explicit representation of the Discrete Fracture Network, faults, and the interface between the Mesozoic unit and the rhyolite unit above. The effectiveness of hydraulic treatment is evaluated considering two types of well completions, open hole and cased borehole, with multistage stimulation. The injection is carried out in six sequential stages along the borehole in order to create a stimulated reservoir. In the open hole model, a low injection rate of $5 \mathrm{~kg} / \mathrm{s}$ is used per segment of the borehole (in each stage) to induce hydraulic shearing. In the cased borehole model, a high injection rate of $80 \mathrm{~kg} / \mathrm{s}$ is used for half an hour in each stage to propagate hydraulic fractures, followed by a low injection rate for four and a half hours to induce hydraulic shearing.

The microseismic cloud shows the shear-stimulated zone to have dimensions for the cased-borehole model of approximately $950 \mathrm{~m}$ long in the direction of the borehole laterals, $1000 \mathrm{~m}$ wide, and $900 \mathrm{~m}$ in height (fig. 7). The volume is highly irregular between the borehole stages along the well depending on the natural joints that are exercised. A pressure communication is observed between stimulation stages along the sub-horizontal lateral. The maximum height growth of the shear stimulation occurs during the last stage (as much as $700 \mathrm{~m}$ above the well in the cased borehole model), but it is positioned back in the earlier stages 1 to 3 . In the cased-borehole treatment, higher magnitude events are observed at the beginning of each stage during the half hour period of higher injection rates and hydraulic fracturing. Cumulative seismic moment tracks the pattern of injected fluid volume (total injected volume is 1.35 million $\mathrm{kg}$ ). In the open-hole treatment, a different pattern of seismicity is observed through time, without periods of higher occurrence rates early in the stages as there are no high-injection periods. Larger magnitudes are observed throughout the injection period after stage 2. Similar to the cased-hole treatment, cumulative seismic moment tracks the injected fluid volume, in this case at an approximately linear rate with the constant injection rate (total injected volume is 0.54 million $\mathrm{kg}$ ).

Maximum moment magnitudes observed in the models are $M_{\mathrm{W}}=2.4$ for the cased-borehole treatment and $M_{\mathrm{w}}=2.1$ for the open hole treatment. Magnitude distributions appear realistic with $b$-values of $b=1.35$ and $b=1.53$ for the cased borehole and open hole models, respectively. The largest events represent slipping of significant portions of the largest fractures (up to $500 \mathrm{~m}$ diameter). The event mechanisms are decomposed into isotropic and deviatoric components. The majority of events show five to 10 percent positive isotropic components, meaning that the events are mostly shear with a small amount of opening.
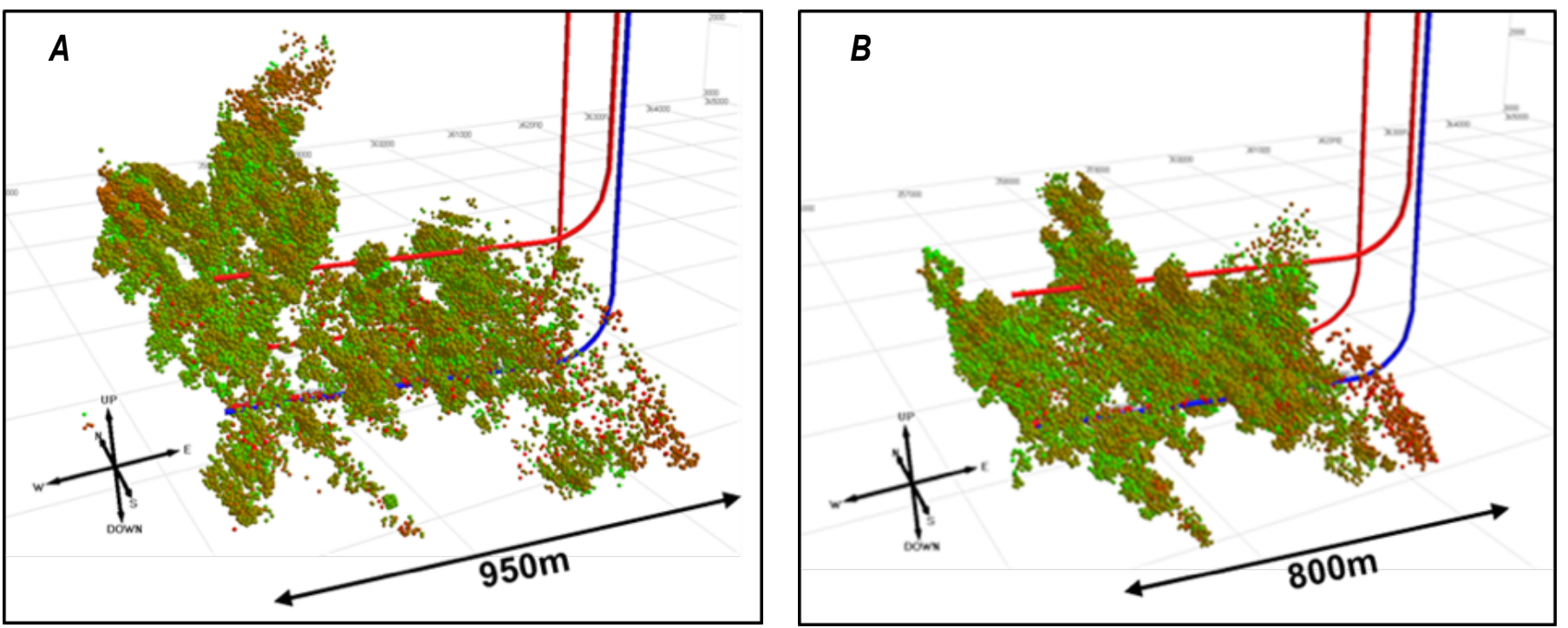

Figure 7. Spatial distribution of the simulated microseismic cloud for the two conceptual treatment designs. $(A)$ : cased-borehole model. $(B)$ open-hole model. The blue well is the injection well. Red wells are the production wells for the side-by-side and over-andunder parallel design options. View is towards the north east. Event colors are plotted by moment magnitude $(M W)$; from green as low as $M N-2.5$ to red being high $M W>1.5$. 


\section{Deterministic Sources: Geomechanical Model - TReactMech}

Very little in situ mechanical and hydrological data exist at the necessary depth-temperature range and at a scale larger than an intact core for most deep low-permeability crustal rocks (Sonnenthal and others, 2018). Thus, we first utilize a native-state model to evaluate the development of the natural hydrological system and thermal regime starting from the geologic model lithology, in order to constrain the range of permeabilities, thermal properties, and boundary conditions (heat fluxes, recharge, etc.) that can adequately capture the observed deep wellbore temperatures, pressures, and geomechanical measurements (Sonnenthal and others, 2018). The native-state model then becomes the basis for the stimulation model, giving more confidence in the initial and boundary conditions, and rock properties.

Steady-state thermal-hydrological models using the parallel thermo-hydro-chemical simulator TOUGHREACT V3.4-OMP show that the range of large-scale permeability in the proposed injection lithology at Fallon is between $10-16$ and $10-17 \mathrm{~m}^{2}$, and most likely less than $10-16 \mathrm{~m}^{2}$ by comparison to measured deep wellbore temperatures (Sonnenthal and others, 2018, Xu and others, 2011). This range is consistent with data from prior flow tests and modeling in other Basin and Range geothermal systems (for example, Davatzes and Hickman, 2009). The steady-state thermal-hydrological models are used as the starting conditions for a geomechanical "steady-state" simulation, using calculated stress orientations and relative magnitudes. Simulations are performed using the new parallel coupled thermo-hydro-mechanical-chemical simulator TReactMech that incorporates the full multiphase flow and reactive-transport capabilities of TOUGHREACT V3.4-OMP with coupled geomechanics. Geomechanics calculations are based on a 3-D continuum finite-element model with full 3-D stress calculations, plastic deformation via shear and tensile failure, coupling of equivalent continuum (fracture and rock matrix) permeability and porosity changes (thermo-poro-elastic and plastic) to fluid flow (Kim and others, 2012; 2015; Sonnenthal and others, 2015; 2018).

A number of stimulation scenarios are evaluated with the assumption of a horizontal borehole consisting of different lengths of packed-off intervals and injection rates and durations. Given the estimated and calibrated initial permeabilities and fracture properties, the models show increases of over 3 orders of magnitude in effective permeability, with some shear failures up to a maximum of about 200 meters from the injection intervals. Tensile failure is limited to the stimulation interval (maximum of 71 meters), with shear failures elsewhere. None of the simulations result in shear failures along or near the block-bounding faults, although the maximum injection duration is limited to two days. Moment magnitudes and seismic $b$-values are calculated directly from the simulation outputs with the assumption that all shear failures result in seismicity. The maximum magnitude of about 1.54 is associated with the highest injection rate $(80 \mathrm{~kg} / \mathrm{s})$ and lower permeability host rock $\left(\mathrm{k}_{\mathrm{NS}}=2.0 \times 10-17 \mathrm{~m}^{2}, \mathrm{k}_{\text {vert }}=\mathrm{k}_{\mathrm{EW}}\right.$ $=1.4 \times 10-17 \mathrm{~m}^{2}$ ). A wide range of $\mathrm{b}$-values are estimated from about 0.83 to 2.29 , with the average for all curves equal to 1.334 . The highest b-value (2.29) is from the high constant wellhead pressure ( $4000 \mathrm{psi}$ or $27.58 \mathrm{MPa}$ ) simulation. Eliminating this from the average $b$-value calculation gives an average $b$-value of 1.08 , for the other 4 injection-schedule simulations. In summary, these model simulations provide confidence that the large-scale permeability is within the desired range, that stimulation of the rock could lead to significant injectivity improvements, and that induced seismicity is likely limited to small magnitude.

\section{Deterministic Sources: Injection and Rigidity Model}

McGarr (1976) proposed that total induced cumulative seismic moment scales with injection volume and the rigidity of the reservoir rock at the Rocky Mountain Arsenal. These relationships were updated to account for a factor of two difference in assumed stress drops (McGarr, 2014), and they continue to hold for a variety of injection scenarios including EGS (Majer and others, 2007).

The procedure assumes an upper limit of cumulative injection for any one injection experiment. The analysis also assumes: (1) the seismogenic faults in the vicinity of the injection are prone to slip; (2) faults are stressed to within a seismic stress drop; and (3) the rock is fully saturated at seismogenic depths. These methods cannot account for the possibility that only a fraction of the injected fluid may cause seismic slip across a reactivated fault (McGarr and Barbour, 2017), but nevertheless they provide a reasonable estimate of maximum magnitudes achieved by injection. Furthermore, these methods have been used and applied to PSHA on several occasions (AltaRock, 2011).

The same material properties and injection volumes that are are used in the geomechanical models and are used to plot the resulting maximum magnitude in figure $8\left(\mathrm{M}_{\mathrm{w}}=2.92\right)$ at $1500 \mathrm{~m}^{3}$ injected. Note that we use this maximum magnitude for all b-values, although the maximum $M_{\mathrm{w}}$ calculated following this method depends on the choice of the $b$-value. We chose the maximum $M_{\mathrm{w}}$ to arrive at conservative estimates in the PSHA.

\section{Deterministic Sources: Analog sites}

Nevada is host to many conventional geothermal sites and has a long history of geothermal energy exploration. However, few EGS experiments have been conducted so far, with one taking place at the Desert Peak Geothermal Field starting in 2010 (Chabora and others, 2012). The hydraulic portion of the EGS stimulation at well 27-15 took place in fall of 2010, in a similar tectonic setting and similar temperature range, albeit closer to an active fault and at shallower depth. Initial hydraulic stimulation consisted of injecting at pressures below $\mathrm{S}_{\text {hmin }}$ to promote shear failure and enhance injectivity by self-propping of existing fractures near well 27-15. Injectivity was moderately improved during this phase, but microseismicity was recorded that extended from the well towards the active geothermal field to the south-southwest. Recorded microseismicity ranged in magnitude 


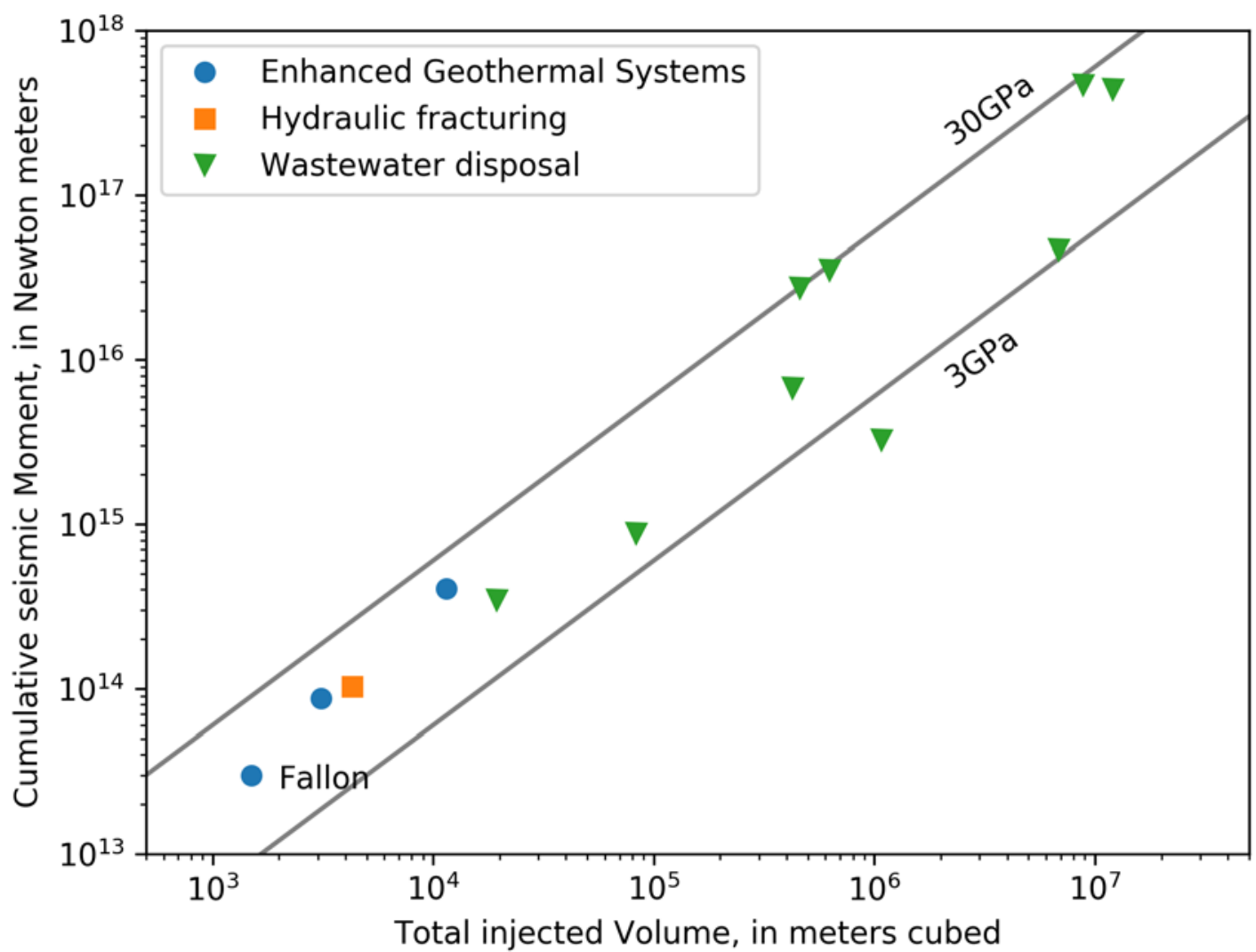

Figure 8. Cumulative seismic moment as a function of total injected volume at various injection sites for a variety of environments. The Frontier Observatory for Research in Geothermal Energy (FORGE) Fallon site is noted as the lowermost blue dot. Gray lines indicate the theoretical relationships with shear moduli of 3 and 30 Giga-Pascal (GPa).

from -1.0 to $1.7 M_{\mathrm{w}}$ (Benato and others, 2016). Given some of the similarities between the two sites and stimulation procedure, the EGS stimulations at Desert Peak between 2010 and 2013 constitutes the most similar analog site to the proposed Fallon EGS stimulation and further informs the epistemic uncertainties in the PSHA for the Fallon site as a whole.

\section{Seismic Hazard Results}

Figures 9 through 12 depict the results of the PSHA for four significant sites near the proposed Fallon FORGE EGS site: NAS Fallon, Banner Churchill Hospital, downtown Fallon, and Rattlesnake Hill (fig. 5). These sites were chosen because they are locations with significant and critical infrastructure. In each of the figures, the median total probability of exceedance of peak ground acceleration (PGA), with the uncertainties of the total probability of exceedance of PGA are depicted as 15th and 85th percentile bounds. The hazard curves at each receiver location are calculated for one EGS stimulation operation (assumed to occur over a period of a week or less), as only during stimulation does the EGS site pose an additional seismic hazard. This is compared to the weekly tectonic (background) seismic hazard from the National Seismic Hazard map at each site (https://earthquake.usgs.gov/ hazards/interactive/).

The 85th percentile ground motions are reported in order to provide conservative estimates of hazard. At NAS Fallon, the closest location to the proposed EGS site having significant and critical infrastructure, the 85th percentile PGA corresponding to a $10^{-3}$ ( 1 in 1000) probability of exceedance is $0.003 \mathrm{~g}$ (fig. 9). Therefore, even at this very low probability of exceedance the estimated ground shaking at the closest site of interest is within the Modified Mercalli Intensity (MMI) III range and would result in noticeable, but weak shaking at most. At the sites within and near the city of Fallon (figs. 10-12) the 85th percentile ground motions at $10^{-3}$ probability of exceedance are less than $0.001 \mathrm{~g}$, below the MMI III threshold of perceptibility. This presents a very low hazard attributable to the proposed EGS stimulation to NAS Fallon and even lower hazard at the sites near the city of Fallon. 
Figure 9. Probability of exceedance of peak ground acceleration (PGA) at the Naval Air Station, Fallon, Nevada. Red line indicates the median probability, whereas the dashed lines show the 15th and 85th percentile of the solution. The weekly tectonic hazard is shown for comparison (green line).

Figure 10. Probability of exceedance of peak ground acceleration (PGA) at the Banner Churchill community hospital. Red line indicates the median probability, whereas the dashed lines show the 15th and 85th percentile of the solution. The weekly tectonic hazard is shown for comparison (green line).
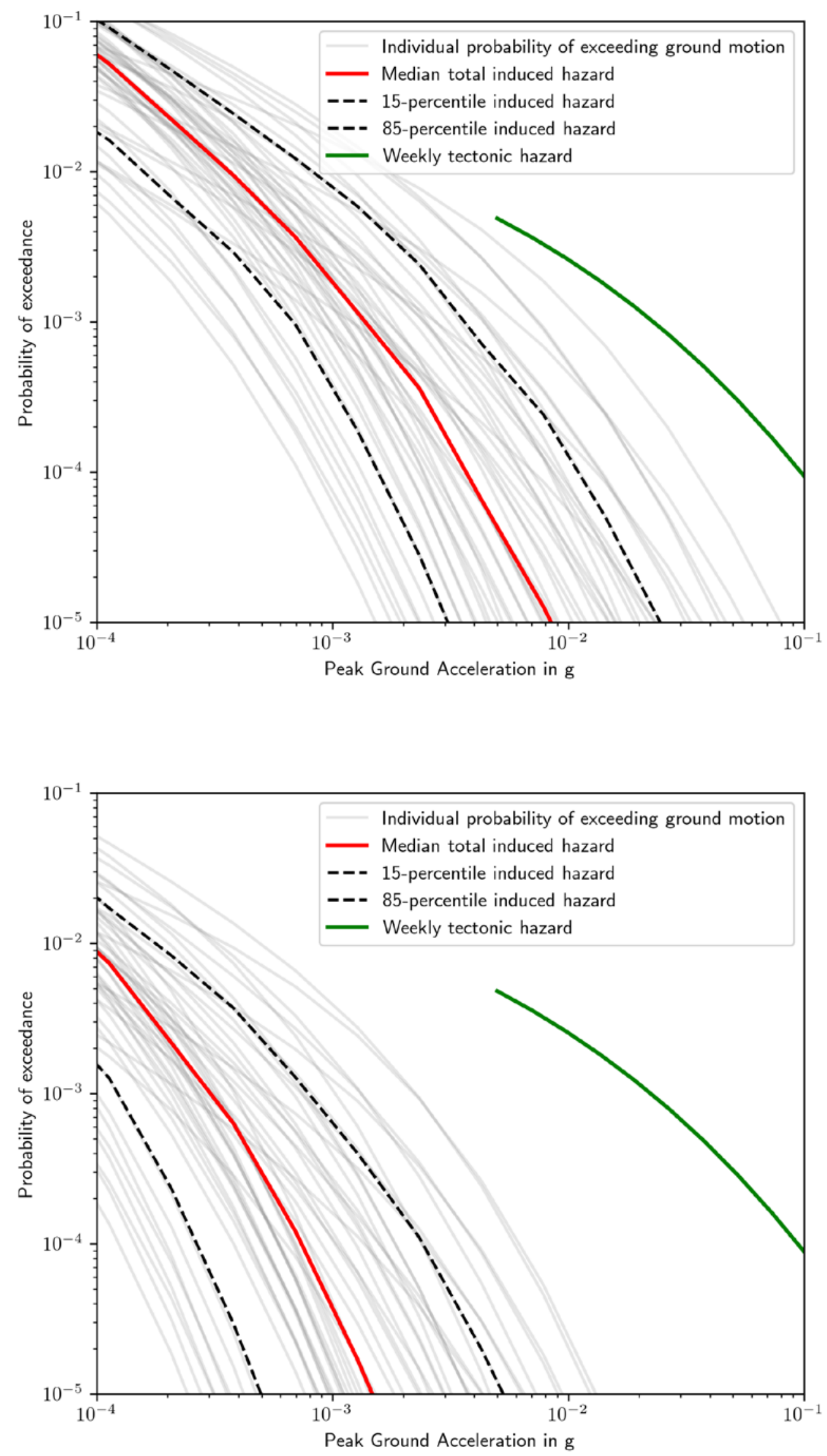

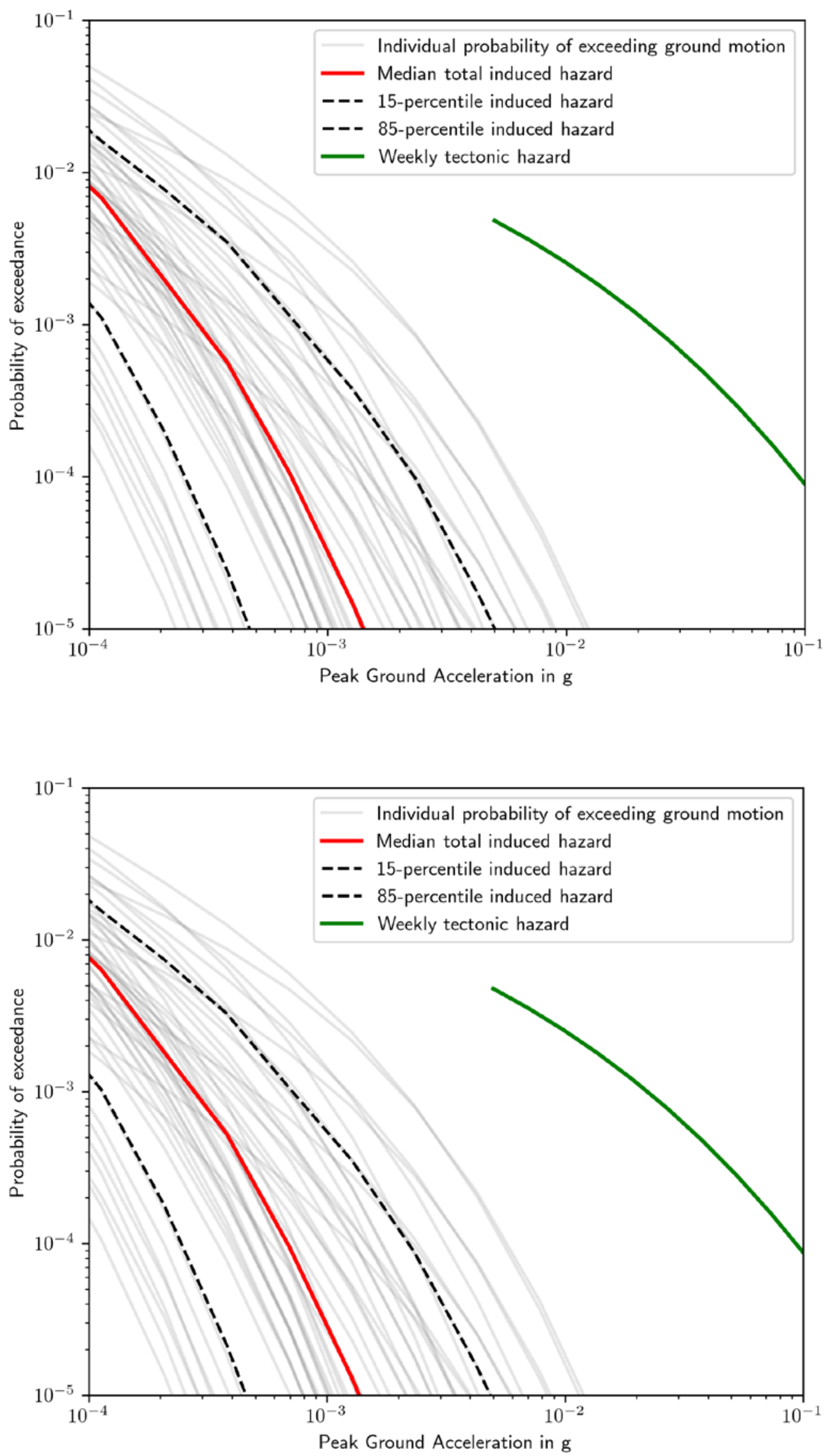

Figure 11. Probability of exceedance of peak ground acceleration (PGA) in downtown Fallon, Nevada. Red line indicates the median probability, whereas the dashed lines show the 15th and 85th percentile of the solution. The weekly tectonic hazard is shown for comparison (green line).

Figure 12. Probability of exceedance of ground motion (PGA) at Rattlesnake Hill (city and Navy water tank site). Red line indicates the median probability, whereas the dashed lines show the 15th and 85th percentile of the solution. The weekly tectonic hazard is shown for comparison (green line). 


\section{Summary}

Standard PSHA practices are employed, and four possible source characterization models are enlisted for expected induced seismicity at the Fallon FORGE EGS stimulation. In addition, partially due to the lack of existing seismicity at the site and partially to arrive at conservative estimates of the hazard, the PSHA is calculated for a range of b-values. Our results indicate that the conservative estimates of seismic hazard at each of the locations having significant, sensitive infrastructure, NAS Fallon, Fallon downtown, Banner Churchill Hospital and Rattlesnake Hill, are very low. NAS Fallon, the location closest to the proposed EGS site, has the highest seismic hazard. This is still very low: a 1/1000 probability of the ground motion resulting from an EGS stimulation exceeding $0.003 \mathrm{~g}$, within the MMI III threshold of perceived weak shaking.

\section{Acknowledgments}

We thank Annemarie Baltay, Andrew Michael, Tom Hanks, Morgan Moschetti, Elizabeth Cochran, and Phil Frederick for insightful reviews that significantly improved the report. The tectonic hazard at the various sites was calculated using the USGS unified hazard tool (https://earthquake.usgs.gov/hazards/ interactive/). The ground motion prediction equations used in the induced seismic hazard analysis were produced using open-quake (https://platform.openquake.org/).

\section{References Cited}

Abrahamson, N.A., Silva, W.J., and Kamai, R., 2014, Summary of the ASK14 ground motion relation for active crustal regions: Earthquake Spectra, v. 30, no. 3, p. 1025-1055.

Allen, T. I., and Wald, D. J., 2009, On the use of high-resolution topographic data as a proxy for seismic site conditions (Vs30): Bulletin of the Seismological Society of America, v. 99, no. 2A, p. 935-943.

AltaRock Energy, 2011, Newberry EGS demonstration induced seismicity mitigation plan, 64 p., 14 app., Available at: http://altarockenergy.com.

Atkinson, G.M., 2015, Ground-motion prediction equation for small-to-moderate events at short hypocentral distances with application to induced-seismicity hazards: Bulletin of the Seismological Society of America, v. 105, no. 2A, p. 981-992.

Baker, J., 2008, An introduction to probabilistic seismic hazard analysis (PSHA): White Paper, Version 1.3, 72 p., Available at: https://web.stanford.edu/ bakerjw/Publications/Baker_(2008)_ Intro_to_PSHA_v1_3.pdf.
Benato, S., Hickman, S.H., Davatzes, N.C., Taron, J., Spielman, P., Elsworth, D., Majer, E.L., and Boyle, K., 2016, Conceptual and numerical model analysis of the Desert Peak EGS projectReservoir response to the shallow medium flow-rate hydraulic stimulation phase: Geothermics, v. 63, p. 139-156.

Blake, K. and Davatzes, N.C., 2012, Borehole image log and statistical analysis of FOH-3D, Fallon Naval Air Station, NV, in Proceedings of the 37th Workshop on Geothermal Reservoir Engineering: Stanford, Calif., Stanford University, $14 \mathrm{p}$.

Blanksma, D.J., Blake, K., Pettitt, W., Sabin, A., Varun, V., and Damjanic, B., 2018, Using borehole induced structure measurements at Fallon FORGE combined with numerical modeling to estimate in-situ stresses, in Proceedings of the 43rd Workshop on Geothermal Reservoir Engineering: Stanford, Calif., Stanford University, 14 p.

Boore, D.M., Stewart, J.P., Seyhan, E., and Atkinson, G.M., 2014, NGA-West2 equations for predicting PGA, PGV, and 5\% damped PSA for shallow crustal earthquakes: Earthquake Spectra, v. 30, p. 1057-1085.

Campbell, K.W., and Bozorgnia, Y., 2014, NGA-West2 ground motion model for the average horizontal components of PGA, PGV, and 5\% damped linear acceleration response spectra: Earthquake Spectra, v. 30, p. 1087-1115.

Caskey, S.J., Bell, J.W., Ramelli, A.R. and Wesnousky, S.G., 2004, Historic surface faulting and paleoseismicity in the area of the 1954 Rainbow Mountain-Stillwater earthquake sequence, Central Nevada: Bulletin of the Seismological Society of America, v. 94, no. 4, p. 1255-1275.

Chabora, E., Zemach, E., Spielman, P., Drakos, P., Hickman, S., Lutz, S., Boyle, K., Falconer, A., Robertson-Tait, A., Davatzes, N.C., Rose, P. Majer, E., and Jarpe, S., 2012, Hydraulic stimulation of well 27-15, Desert Peak Geothermal Field, Nevada, USA, in Workshop on Geothermal Reservoir Engineering, 37th, Stanford, Calif., 2012, Proceedings: Stanford, Calif., Stanford University, 12 p.

Chiou, B.S.-J., and Youngs, R.R., 2014, Update of Chiou and Youngs NGA model for the average horizontal component of peak ground motion and response spectra: Earthquake Spectra, v. 30, p. 1117-1153.

Dash, Z.V., Murphy, H.D., and Cremer, G.M., 1981, Summary of Hot-Dry-Rock Geothermal Reservoir Testing 1978-1980. Los Alamos, NM: Los Alamos National Laboratory, NM. Report No.: LA-9080-SR.

Davatzes, N.C. and Hickman, S.H., 2009. Fractures, Stress and Fluid Flow Prior to Stimulation of Well 27-15, Desert Peak, Nevada, EGS Project, in Workshop on Geothermal Reservoir Engineering, 34 ${ }^{\text {th }}$, Stanford, Calif., 2009. Proceedings: Stanford, Calif., Stanford University, 11 p. 
Douglas, J., Edwards, B., Convertito, V., Sharma, N., Tramelli, A., Kraaijpoel, D., Cabrera, B.M., Maercklin, N., and Troise, C., 2013, Predicting ground motion form induced earthquakes in geothermal areas: Bulletin of the Seismological Society of America, v. 103, no. 3, p. 1875-1897.

Faulds, J.E., Coolbaugh, M.F., Benoit, D., Oppliger, G., Perkins, M., Moeck, I., and Drakos, P., 2010, Structural controls of geothermal activity in the northern Hot Springs Mountains, western Nevada-The tale of three geothermal systems (Brady’s, Desert Peak, Desert Queen): Geothermal Resources Council Transactions, v. 34, p. 675-683.

Faulds, J.E. and Henry, C.D., 2008, Tectonic influences on the spatial and temporal evolution of the Walker Lane-An incipient transform fault along the evolving Pacific-North American plate boundary, in Spencer, J.E. and Titley, S.R. eds., Circum-Pacific Tectonics, Geologic Evolution and Ore Deposits: Tucson, Arizona Geological Society, no. 22, p. $437-470$.

Goebel, T.H.W., Weingarten, M., Chen, X., Haeffner, J. and Brodsky, E.E., 2017, The 2016 Mw5.1 Fairview, Oklahoma earthquakes - Evidence for long-range poroelastic triggering at $>40 \mathrm{~km}$ from disposal wells: Earth and Planetary Science Letters, v. 472, p. 50-61.

Hammond, W.C., Blewitt, G., and Kreemer, C., 2014, Steady contemporary deformation of the central Basin and Range Province, western United States: Journal of Geophysical Research, 119 p., https://doi.org/10.1002/2014JB011145.

Hickman, S.H. and Davatzes, N.C., 2010, In-situ stress and fracture characterization for planning if an EGS stimulation in the Desert Peak geothermal field, Nevada, in Proceedings of the 35th Workshop on Geothermal Reservoir Engineering: Stanford, Calif., Stanford University, 13 p.

Hinz, N.H., Faulds, J.E. and Coolbaugh, M.F., 2014, Association of fault terminations with fluid flow in the Salt Wells Geothermal Field, Nevada, USA: Geothermal Resources Council, v. 38, 10 p.

Idris, I.M., 2014, An NGA-West2 Empirical Model for Estimating the Horizontal Spectral Values Generated by Shallow Crustal Earthquakes: Earthquake Spectra, v. 30, no. 3, p. 1155-1177.

Jolie, E., Moeck, I. and Faulds, J.E., 2015, Quantitative structural-geological exploration of fault controlled geothermal systems - a case study from the Basin and Range province, Nevada (USA): Geothermics, v. 54, p. 54-67.

Kim, J. and Sonnenthal, E., and Rutqvist, J., 2012, Formulation and Sequential Numerical Algorithms of Coupled Fluid/Heat Flow and Geomechanics for Multiple Porosity Materials: International Journal of Numerical Methods in Engineering, v. 92 , p. $425-456$.
Kim, J., and Sonnenthal, E. and Rutqvist, J., 2015, A Sequential Implicit Algorithm of Chemo-Thermo-Poro-Mechanics for Fractured Geothermal Reservoirs: Computers \& Geosciences, v. 76, p. 59-71.

Kim, K.-H., Ree, J.-H., Kim, Y. Kang, S.U. and Seo, W., 2018, Assessing whether the $2017 \mathrm{Mw} 5.4$ Pohang earthquake in South Korea was an induced event: Science, v. 360, p. 1007-1009, https://doi.org/10.1126/science.aat6081.

Kraft, T. and Deichmann, N., 2014, High-precision relocation and focal mechanism of the injection-induced seismicity at the Basel EGS: Geothermics, v. 52, p. 59-73.

Kreemer, C., Hammond, W.C., Blewitt, G., Holland, A.A., and Bennett, R.A., 2012, A geodetic strain rate model for the Pacific-North American plate boundary, western United States, Nevada Bureau of Mines and Geology Map 178, 1 sheet, scale 1:1,500,000.

Majer, E.M., Baria, R., Stark, M., Oates, S., Bommer, J. Smith, B., Asanuna, H., 2007, Induced seismicity associated with enhanced geothermal systems: Geothermics, v. 36, p. $185-222$.

Majer, E., Nelson, J., Robertson-Tait, A., Savy, J., and Wong, I., 2012, Protocol for Addressing Induced Seismicity Associated with Enhanced Geothermal Systems (EGS): U.S. Department of Energy, 52 p. Available at: http://www1.eere.energy.gov/ geothermal/pdfs/geothermal_seismicity_protocol_012012.pdf.

McGarr, A.F., 1976, Seismic Moment and volume changes: Journal of Geophysical Research, v. 81, p. 1487-1494.

McGarr, A.F., 2014, Maximum magnitude earthquakes induced by fluid injection: Journal of Geophysical Research, no. 199, p. 1008-1019.

McGarr, A.F. and Barbour, A.J., 2017, Wastewater disposal and the earthquake sequences during 2016 near Fairview, Pawnee, and Cushing, Oklahoma: Geophysical Research Letters, v. 44, no. 18, p. 9330-9336.

McGuire, R.K., 2004, Seismic hazard and risk analysis: Berkeley, Calif., Earthquake Engineering Research Institute, $221 \mathrm{p}$.

Molnar, P., 1979, Earthquake recurrence intervals and plate tectonics: Bulletin of the Seismological Society of America, v. 69 , no. 1 , p. $115-133$.

Morrison, R.B., 1964, Lake Lahontan-Geology of the Southern Carson Desert, Nevada: U.S. Geological Survey Professional Paper 401, 156 p.

Parsons, T., 1995, The Basin and Range Province, in Olsen, K., ed., Continental Rifts: Evolution, Structure and Tectonics, New York, Elsevier Science, p. 277-324. 
Siler, D.L., Hinz, N.H., Faulds, J.E., Tobin, B., Blake, K., Tiedeman, A., Sabin, A., Lazaro, M., Blankenship, D., Kennedy, M., Rhodes, G., Hickman, S., Glen, J., Williams, C., Robertson-Tait, A., and Pettitt, W., 2016. The Geologic Framework of the Fallon FORGE Site: Geothermal Resources Council Transactions, v. 40, 17 p.

Siler, D.L., Hinz, N.H., Faults, J.E., Ayling, B., Blake, K., Tiedemann, A., Sabin, A., Blankenship, D., Kennedy, B.M. Rhodes, G., Sophy, M.J. Glen, J.M.G., Phelps, G.A., Fortuna, M., Queen, J., and Witter, J.B., 2018, The Geologic and Structural Framework of the Fallon FORGE site, in Proceedings 43rd Workshop on Geothermal Reservoir Engineering, Stanford, Calif., Stanford University, 7 p.

Sonnenthal, E. Smith, J.T., and Cladohous, T.T., 2015, ThermoHydrological-Mechanical-Chemical Modeling of the 2014 EGS Stimulation Experiment at Newberry Volcano, Oregon, in Proceedings 40th Workshop on Geothermal Reservoir Engineering, Stanford, Calif., Stanford University, 5 p.
Sonnenthal, E., Pettitt, W., Smith, T., Riahi, A., Siler, D. Kennedy, M., Majer, E.L., Dobson, P. Ayling, B., Damjanac, B., and Blankenship, D., 2018, Continuum Thermal-HydrologicalMechanical Modeling of the Fallon FORGE Site: Geothermal Resources Council Transactions, v. 42, 11 p.

Stewart, J.H., 1988, Tectonics of the Walker Lane belt, western Great Basin-Mesozoic and Cenozoic deformation in a zone of shear, in Ernst, W.G., ed., Metamorphism and Crustal Evolution of the Western United States: Englewood Cliffs, N.J., PrenticeHall, p. 683-713.

Thatcher, W., Foulger, G.R., Julian, B.R., Svarc, J., Quilty, E., and Bawden, G.W., 1999, Present-Day Deformation across the Basin and Range Province, Western United States: Science, v. 283 , p. $1714-1717$. 
Menlo Park Publishing Service Center

Manuscript approved February, 28, 2019

Edited by Phil Frederick

Layout by Cory Hurd 
